University of Wollongong

Research Online

Australian Institute for Innovative Materials -

Papers

Australian Institute for Innovative Materials

2013

PdNi hollow nanoparticles for improved electrocatalytic oxygen reduction in alkaline environments

Meng Wang

University of Wollongong, mw088@uowmail.edu.au

Weimin Zhang

Shanghai Sinopoly Batteries Research Institute, weimin@uow.edu.au

Jiazhao Wang

University of Wollongong, jiazhao@uow.edu.au

David Wexler

University of Wollongong, davidw@uow.edu.au

Simon D. Poynton

University of Surrey

See next page for additional authors

Follow this and additional works at: https://ro.uow.edu.au/aiimpapers

Part of the Engineering Commons, and the Physical Sciences and Mathematics Commons

Research Online is the open access institutional repository for the University of Wollongong. For further information contact the UOW Library: research-pubs@uow.edu.au 


\title{
PdNi hollow nanoparticles for improved electrocatalytic oxygen reduction in alkaline environments
}

\author{
Abstract \\ Palladium-Nickel (Pd-Ni) hollow nanoparticles were synthesized via a modified galvanic replacement \\ method using Ni nanoparticles as sacrificial templates in an aqueous medium. X-ray diffraction and \\ transmission electron microscopy show that the as-synthesized nanoparticles are alloyed nanostructures \\ and have hollow interiors with an average particle size of $30 \mathrm{~nm}$ and shell thickness of $5 \mathrm{~nm}$. Compared \\ with the commercially available $\mathrm{Pt} / \mathrm{C}$ or $\mathrm{Pd} / \mathrm{C}$ catalysts, the synthesized $\mathrm{PdNi} / \mathrm{C}$ has superior \\ electrocatalytic performance towards the oxygen reduction reaction, which makes it a promising \\ electrocatalyst for alkaline anion exchange membrane fuel cells and alkali-based air-batteries. The \\ electrocatalyst is finally examined in an $\mathrm{H} 2 / 02$ alkaline anion exchange membrane fuel cell; the results \\ show that such electrocatalysts could work in a real fuel cell application as a more efficient catalyst than \\ state-of-the-art commercially available $\mathrm{Pt} / \mathrm{C}$.
}

\section{Keywords}

reduction, alkaline, environments, pdni, nanoparticles, hollow, improved, electrocatalytic, oxygen

\section{Disciplines}

Engineering | Physical Sciences and Mathematics

\section{Publication Details}

Wang, M., Zhang, W., Wang, J., Wexler, D., Poynton, S. D., Slade, R. C.T., Liu, H., Winther-Jensen, B., Kerr, R., Shi, D. \& Chen, J. (2013). PdNi hollow nanoparticles for improved electrocatalytic oxygen reduction in alkaline environments. ACS Applied Materials and Interfaces, 5 (23), 12708-12715.

\section{Authors}

Meng Wang, Weimin Zhang, Jiazhao Wang, David Wexler, Simon D. Poynton, Robert C.T Slade, Hua-Kun Liu, Bjorn Winther-Jensen, Robert Kerr, Dongqi Shi, and Jun Chen 


\section{PdNi Hollow Nanoparticles for Improved Electrocatalytic}

\section{Oxygen Reduction in Alkaline Environments}

Meng Wang, ${ }^{1}$ Weimin Zhang, ${ }^{2}$ Jiazhao Wang, ${ }^{3}$ David Wexler, ${ }^{4}$ Simon D. Poynton, ${ }^{5}$ Robert C.T. Slade, ${ }^{5}$ Hua Kun-Liu, ${ }^{2}$ Bjorn Winther-Jensen, ${ }^{6}$ Robert Kerr, ${ }^{6}$ Dongqi Shi, ${ }^{3}$ Jun Chen ${ }^{1 *}$

${ }^{1}$ ARC Centre of Excellence for Electromaterials Science, Intelligent Polymer Research Institute, Australian Institute of Innovative Materials, University of Wollongong, Wollongong, NSW 2500, Australia

${ }^{2}$ Shanghai Sinopoly Batteries Research Institute, Shanghai, 200241, China

${ }^{3}$ Institute for Superconducting and Electronic Materials, University of Wollongong, Wollongong, NSW 2500, Australia

${ }^{4}$ School of Mechanical, Materials and Mechatronic Engineering, University of Wollongong, Wollongong, NSW 2500, Australia

${ }^{5}$ Department of Chemistry, University of Surrey, Guildford, Surrey GU2 7XH, United Kingdom

${ }^{6}$ Department of Materials Engineering, Monash University, Clayton VIC 3800, Australia

\section{ABSTRACT}

Palladium-Nickel (Pd-Ni) hollow nanoparticles were synthesized via a modified galvanic replacement method using Ni nanoparticles as sacrificial templates in an aqueous medium. X-ray 
diffraction and transmission electron microscopy show that the as-synthesized nanoparticles are alloyed nanostructures and have hollow interiors with an average particle size of $30 \mathrm{~nm}$ and shell thickness of $5 \mathrm{~nm}$. Compared with the commercially available $\mathrm{Pt} / \mathrm{C}$ or $\mathrm{Pd} / \mathrm{C}$ catalysts, the synthesized $\mathrm{PdNi} / \mathrm{C}$ has superior electrocatalytic performance towards the oxygen reduction reaction, which makes it a promising electrocatalyst for alkaline anion exchange membrane fuel cells and alkali-based air-batteries. The electrocatalyst is finally examined in an $\mathrm{H}_{2} / \mathrm{O}_{2}$ alkaline anion exchange membrane fuel cell; the results show that such electrocatalysts could work in a real fuel cell application as a more efficient catalyst than state-of-the-art commercially available $\mathrm{Pt} / \mathrm{C}$.

\section{KEYWORDS}

Palladium Nickel, hollow, bimetallic, oxygen reduction reaction, alkaline membrane fuel cell 


\section{Introduction}

The oxygen reduction reaction (ORR) has been recognised as the kinetically limiting step in fuel cells and metal-air batteries due to sluggish reaction kinetics. ${ }^{1-2}$ Platinum $(\mathrm{Pt})$, the most efficient electrocatalyst for the ORR, is inhibited from large-scale commercialisation due to high cost, poor stability, and poor poisons resistance. ${ }^{3-5}$ It has been well documented that the overpotential for the ORR will be significantly reduced in high $\mathrm{pH}$ (alkaline) environment, thus offering the possibilities of lower usage and wider selection of electrocatalysts other than platinum to be available for this catalytic reaction, ${ }^{6-7}$ while recent advances in the development of alkaline anion exchange membranes (AAEMs) has also seen the performance of anion exchange membrane fuel cell (AEMFC) approach that of the analogous, conventional acidic Nafion ${ }^{\circledR}$ proton exchange membrane fuel cell (PEMFC). ${ }^{8-10}$ This adds further incentive to the need to develop novel nanostructured electrocatalysts for the ORR in alkaline medium.

Palladium (Pd), with competitive intrinsic electrocatalytic performance towards the ORR compared to $\mathrm{Pt}$, is less expensive and more abundant and has received considerable attention recently. ${ }^{7,}{ }^{11-14} \mathrm{Pd}$ alloyed with transition metals (Pd-TMs), such as $\mathrm{Pd}-\mathrm{Ni},{ }^{15-16} \mathrm{Pd}-\mathrm{Cu},{ }^{17-20} \mathrm{Pd}-$ $\mathrm{Fe}^{7,21-22}$ and $\mathrm{Pd}-\mathrm{Co},{ }^{23}$ has proven to be an effective way to reduce cost and simultaneously to enhance catalytic performance. ${ }^{7,24}$ Compared with alloying with noble metals such as Pd-Au ${ }^{11,}$ 25-26 or Pd-Ag, ${ }^{6,24,27} \mathrm{Pd}$ alloyed with TMs provides a more practical and economical way to produce Pd-based bimetallic electrocatalysts for the ORR in alkaline media.

Among these bimetallic electrocatalysts, hollow structures are proving to be economically viable, while they are also more efficient catalysts due to their higher surface area and catalyst utilization efficiency compared with their filled solid counterparts. ${ }^{28}$ The so called sacrificial template protocol (galvanic replacement), which was first well demonstrated by Xia's group ${ }^{29}$, 
has been modified and widely applied to synthesise nanocrystals with hollow features. ${ }^{30}$ Pt-based bimetallic hollow nanostructures such as Pt-Pd, ${ }^{51} \mathrm{Pt}-\mathrm{Ag},{ }^{32}$ and $\mathrm{Pt}-\mathrm{TMs}\left(\mathrm{Pt}-\mathrm{Co},{ }^{33-34} \mathrm{Cu},{ }^{28}\right.$ and $\mathrm{Ni}^{35}$ ) with enhanced electrocatalytic performance have been reported. In comparison with the development of Pt-bimetallic hollow nanostructures, reports on synthesising Pd-based bimetallic hollow nanostructures have been rare, mainly because the activity and the durability of Pd in the ORR are poor in acidic media. ${ }^{7}$ For example, Pd-Ag hollow nanorings were synthesized with good methanol tolerance, ${ }^{27}$ while the ORR performance was not improved, mainly because the larger lattice constant of silver would subject the Pd to a tensile strain effect, decreasing the electroactivity of $\mathrm{Pd}$ towards the ORR. ${ }^{36} \mathrm{Pd}-\mathrm{Co}^{37}$ and $\mathrm{Pd}-\mathrm{Cu}^{38}$ hollow nanostructures were also reported with large particle size $(>50 \mathrm{~nm})$ but their ORR properties were not extensively studied due to the large particle size, which may decrease the active surface area. Thus, there is still an urgent need to develop Pd-TM bimetallic hollow nanostructures with catalytic oxygen reduction abilities in alkaline media.

In this report, we present novel hollow $\mathrm{PdNi}$ nanostructures synthesized via a modified galvanic process using $\mathrm{Ni}$ nanoparticles as sacrificial templates in aqueous solution. Electrochemical testing to investigate the ORR effects showed that the as-synthesized PdNi had an outstandingly high mass activity of $588.97 \mathrm{~mA} \mathrm{~g}^{-1}$, which is 3.9 times higher than that of $\mathrm{Pt} / \mathrm{C}$, when the precursor ratio of $\mathrm{Pd}: \mathrm{Ni}$ was $1: 1$ (denoted as $\mathrm{Pd}_{1} \mathrm{Ni}_{1}$ in this report) at $-0.114 \mathrm{~V}$ (vs. $\mathrm{Ag} / \mathrm{AgCl}$ ). Together with single $\mathrm{H}_{2} / \mathrm{O}_{2}$ fuel cell testing, it is evidenced that $\mathrm{Pd}_{1} \mathrm{Ni}_{1} / \mathrm{C}$ could serve as an efficient and durable AEMFC electrocatalyst in a practical working device.

\section{EXPERIMENTAL SECTION}

Chemicals 
Nickel(II) chloride hexahydrate $\left(\mathrm{NiCl}_{2} \cdot 6 \mathrm{H}_{2} \mathrm{O}\right)$, palladium(II) chloride $\left(\mathrm{PdCl}_{2}\right)$, sodium citrate (99\%), and sodium borohydride $\left(\mathrm{NaBH}_{4}, 99.99 \%\right)$ were purchased from Sigma-Aldrich. Carbon black (CB, Vulcan XC-72 R) was provided by the Cabot Corporation. All glassware and PTFEcoated magnetic stir bars were cleaned with aqua regia, followed by copious rinsing with distilled water before drying in an oven.

Synthesis

Ni nanoparticles were synthesized using the borohydride reduction method. Briefly, $0.02 \mathrm{mmol}$ $\mathrm{NiCl}_{2} \cdot 6 \mathrm{H}_{2} \mathrm{O}$ and $29.4 \mathrm{mg}$ sodium citrate were added to $40 \mathrm{ml}$ distilled water. After deoxygenating with nitrogen for $15 \mathrm{~min}, 2 \mathrm{ml}$ freshly prepared $\mathrm{NaBH}_{4}(7.5 \mathrm{mg})$ was injected into the solution by syringe. The colour of the solution immediately turned dark yellow after the addition of $\mathrm{NaBH}_{4}$, indicating the formation of Ni nanoparticles. After a few minutes, $0.02 \mathrm{mmol}$ $\mathrm{H}_{2} \mathrm{PdCl}_{4}$ in $40 \mathrm{ml}$ deoxygenated water was added dropwise into the Ni particle/colloid at a rate of $1 \mathrm{ml} \mathrm{min}-1$ and allowed to react for another 2 hours. The synthesized PdNi nanoparticles were supported on carbon black (CB, Vulcan XC-72 R, Cabot Corp.) with a loading of 20 mass\%, achieved by mixing the above colloids with acid treated CB. A solid sample was obtained by filtration. Before filtration, an aliquot of sodium hydroxide was added with stirring for another 2 hours, and then the products were filtered and rinsed with water several times to remove the residual impurities in the catalysts, and then dried at $80^{\circ} \mathrm{C}$ overnight. This sample was denoted as $\mathrm{Pd}_{1} \mathrm{Ni}_{1} / \mathrm{C}$. To determine the optimized molar ratio of $\mathrm{Pd}: \mathrm{Ni}, \mathrm{PdNi} / \mathrm{C}$ catalysts with various precursor mole ratios of $\mathrm{Pd}$ to $\mathrm{Ni}, 3: 1,2: 1,1: 1$, and $0.5: 1$, were synthesized. The corresponding samples were denoted as $\mathrm{Pd}_{3} \mathrm{Ni}_{1} / \mathrm{C}, \mathrm{Pd}_{2} \mathrm{Ni}_{1} / \mathrm{C}, \mathrm{Pd}_{1} \mathrm{Ni}_{1} / \mathrm{C}$, and $\mathrm{Pd}_{0.5} \mathrm{Ni}_{1} / \mathrm{C}$ respectively.

\section{Physical Characterization}


Low magnification TEM images were collected with a JEOL JEM-2100F transmission electron microscope (TEM). High resolution (HR)-TEM images, scanning transmission electron microscope (STEM) images, and probe-corrected energy dispersive spectroscopy (EDS) line scans were collected in high-angle annular dark-field imaging (HAADF)-STEM mode, using a JEOL-JEM 2200FS TEM operated at $200 \mathrm{kV}$. Samples for TEM were prepared by dropping one drop of the cleaned nanoparticles in ethanol dispersion on a copper grid (200 mesh). The powder X-ray diffraction (XRD) patterns were collected using a Bruker D8-Advance X-ray powder diffractometer with $\mathrm{Cu} \mathrm{K \alpha}$ radiation $(\lambda=1.5406 \AA$ ). X-ray photoelectron spectroscopy (XPS) spectra were collected using a Thermo Scientific K-Alpha instrument. Metal contents of the products were determined using energy dispersive spectroscopy (EDS, Bruker) in SEM (JEOL7500FA) and inductively coupled plasma - mass spectrometry (ICP-MS 7500CS, Agilent Technologies).

Electrochemical measurements

Electrochemical measurements were performed using the thin film rotating-disk electrode (TFRDE) technique, as reported elsewhere. ${ }^{39}$ The thin film electrode was prepared through placing $10 \mu \mathrm{L}$ of the catalyst ink on a glassy carbon rotating disk electrode (RDE, $0.1925 \mathrm{~cm}^{2}$, Pine Research Instrumentation). The electrocatalyst ink was prepared by dispersing the electrocatalyst in Nafion/ $\mathrm{H}_{2} \mathrm{O} /$ isopropanol $(\mathrm{m} / \mathrm{m} / \mathrm{m}=0.05 / 10 / 50)$ to obtain a $2 \mathrm{mg} \mathrm{ml}^{-1}$ dispersion via a sonicator (Brandson). The electrode was then connected to a $\mathrm{CHI} 720 \mathrm{c}$ bipotentiostat $(\mathrm{CH}$ Instruments) in a standard three-electrode cell with a Pt-mesh counter electrode and a $\mathrm{KCl}(\mathrm{aq})$ saturated $\left(3 \mathrm{~mol} \mathrm{~L}^{1}\right) \mathrm{Ag} / \mathrm{AgCl}$ reference. Unless otherwise specified, all the potentials are against $\mathrm{Ag} / \mathrm{AgCl}$ as reference potential. 
The cyclic voltammetry $(\mathrm{CV})$ traces were recorded in $\mathrm{N}_{2}$-Saturated $\mathrm{KOH}(\mathrm{aq})\left(0.1 \mathrm{~mol} \mathrm{~L}^{-1}\right)$ solution with a sweep rate of $50 \mathrm{mV} \mathrm{s}^{-1}$. The ORR polarization curves were recorded using a linear sweep voltammetry (LSV) technique in oxygen saturated electrolyte with a sweep rate of $10 \mathrm{mV} \mathrm{s}^{-1}$ at various rotation speeds of $100,400,900$, and $1600 \mathrm{rpm}$ from 0.1 to $-0.8 \mathrm{~V}$. Stability tests were carried out by the chronoamperometry technique at the potential of $-0.2 \mathrm{~V}$ and with rotation at $1600 \mathrm{rpm}$ in oxygen-saturated electrolyte for 8000 seconds.

\section{Single Fuel Cell Test}

The anion-exchange membranes used were electron-beam-grafted EFTE membranes (graft copolymerised) using vinylbenzyl chloride and functionalised using trimethylamine (University of Surrey); ${ }^{10}$ the membrane used was of type S80, with membrane thickness $\approx 80 \mu \mathrm{m}$ (thickness depends on hydration level) and ion exchange capacity IEC $\approx 1.3 \mathrm{meq} \mathrm{g}^{-1}$. The anodes and cathodes were prepared as described previously. ${ }^{10}$ In brief, the electrocatalyst ink with ca. 10 mass\%. PTFE as binder were firstly sprayed on the gas diffusion layers (GDLs, $5 \mathrm{~cm}^{2}$ ) to a loading of $0.4 \mathrm{mg} \mathrm{cm}^{-2}$ and were then spray-treated with poly(vinybenzyl chloride) dissolved in ethyl acetate. The prepared GDLs were subsequently immersed in undiluted $N, N, N^{\prime}, N^{\prime}-$ tetramethylhexane-1,6-diamine (TMEDA) for 24 hours and then washed thoroughly with water. The Pt/C was used as the electrocatalysts for anodes. For comparison purpose, the commercial ETek Pt/C and the $\mathrm{Pd}_{1} \mathrm{Ni}_{1} / \mathrm{C}$ were chosen and used as catalysts for cathodes. Before single fuel cell testing, the AAEMs and GDL electrodes were immersed in $\mathrm{KOH}(\mathrm{aq})\left(1 \mathrm{~mol} \mathrm{~L}^{-1}\right)$ solution for 1 hour to give alkaline anion-exchange materials $\left(\mathrm{OH}^{-}\right.$conducting polymer electrolyte and crosslinked ionomer). The membrane electrode assemblies (MEAs) were preparing by sandwiching the anode GDLs and the AAEMs and tested using an 850e fuel cell test system (Fuel Cell Technologies, Inc., USA) fed with humidified hydrogen and oxygen. The gas flow was 
controlled at $0.08 \mathrm{ml} \mathrm{min}^{-1}$. The fuel cell measurements were carried out at $60^{\circ} \mathrm{C}$ under 15 psi (103 $\mathrm{kPa}$ ) back pressure. The polarization curves were recorded using a potential scan method by holding the cell at each potential for $30 \mathrm{~s}$ in order to obtain the steady-state current value with a scan rate of $25 \mathrm{mV} \mathrm{s}^{-1}$ from $0.90 \mathrm{~V}$ to $0.25 \mathrm{~V}$.

\section{Results and Discussion}

A schematic illustration of the synthesis of PdNi hollow nanoparticles is presented in Figure 1, which is quite similar to the mechanism proposed in our previous work. ${ }^{40}$ As the standard reduction potential of $\mathrm{Ni}(\mathrm{II}) / \mathrm{Ni}(-0.257 \mathrm{~V}$ vs. standard hydrogen electrode (SHE)) is lower than that of the $\mathrm{PdCl}_{4}^{2-} / \mathrm{Pd}$ couple $(0.59 \mathrm{~V}$ vs. SHE), once dihydrogen tetrachloropalladate(II) solution is added the galvanic replacement will occur immediately $\left(2 \mathrm{Ni}+\mathrm{PdCl}_{4}^{2-} \rightarrow 2 \mathrm{Ni}^{2+}+\mathrm{Pd}+\right.$ $4 \mathrm{Cl}^{-}$). In this process, Ni nanoparticles serve as the template and are gradually consumed by $\mathrm{Pd}$ salts, thereby forming hollow cores. The Pd(II) ions will be co-reduced with a certain amount of $\mathrm{Ni}$ (II) (leached away during the previous process) and to be deposited on the surface of the $\mathrm{Ni}$ nanoparticles and form PdNi alloy shells.

Morphologies of the nanoparticles thus produced were examined by TEM (Figure 2(A) and (B)). It is clear that the nanoparticles are mostly well dispersed, with the shell color much darker than the inside core, suggesting hollow-featured nanostructures. The average diameter of the hollow spheres is ca. $30 \mathrm{~nm}$, and the shell thickness of 5-7 nm. Another feature of the hollow nanoparticles is that their shells are constructed from numerous discontinuous grains (crystalline alloy particles (Figure $1(\mathrm{C})$ ) with an average size of 3-5 nm, which indicates that the shells are incomplete and porous. This mechanism could be explained by the faster reaction kinetics of $\mathrm{Pd} / \mathrm{Ni}$, as proposed in our previous report. ${ }^{40}$ The selected area electron diffraction (SAED) 
pattern (inset, Figure 2(B)) indicates that the nanoparticles are polycrystalline nanocrystals with a face-centred-cubic $(f c c)$ structure. The $d$-spacing of lattice fringes determined from the HRTEM images (Figure 2(C) inset) is $0.216 \mathrm{~nm}$, corresponding to the (111) planes of the PdNi alloy nanostructure. Probe-corrected HAADF-STEM EDS line scan analysis (Figure 2(D)) was further used to determine the elemental distribution within the nanoparticles. As is shown, $\mathrm{Pd}$ and $\mathrm{Ni}$ are both distributed through the particles, with more Pd aggregated on the shell. In addition, more of the elements were detected on the shell than in the core, reflecting the formation of a hollow shape.

Impacts of the precursors' molar ratio on the morphology of the nanoparticles were carefully examined, as shown in Figure 3. When the precursor ratio $\mathrm{Pd} / \mathrm{Ni}$ is $\geq 3$, the hollow feature can barely be observed due to the relatively thick shells of the nanoparticles (>10 nm, Figure 3(A)). The shell thickness decreases, and the particle size slightly increases, with reduction of the Pd proportion. As a consequence, well-defined hollow shapes gradually appear. When the ratio of $\mathrm{Pd} / \mathrm{Ni}$ is 0.5 in the precursor, some smaller nanoparticles with sizes of about $15 \mathrm{~nm}$ are also produced (Figure 3(D)), which may be because the Pd ions were insufficient to consume all the Ni nanoparticles to form hollow shapes in the solution, causing the thus produced nanoparticles to be partially solid. This was evidenced by the single Ni peak on the XRD patterns (Figure 4(B)). The shell porosity was also changed when the ratio in the precursors was varied; with less Pd, the shell tended to be more porous.

XRD was employed to analyse the crystal structures of the hollow PdNi particles, as shown in Figure 4(B). The diffraction peaks indicated that the structure could be indexed using a facecentred-cubic $(f c c)$ lattice, with (111), (200), (220), and (311) crystal planes forming the facets. In comparison to the pure $\mathrm{Pd} / \mathrm{C}$ (JCPDS 89-4897), the four characteristic peaks of $\mathrm{PdNi} / \mathrm{C}$ are 
noticeably shifted toward higher diffraction angles, suggesting the formation of $\mathrm{Pd} / \mathrm{Ni}$ alloyed nanostructures. Moreover, a single pure Pd peak was not detected, indicating that all the Pd is in the alloyed state.

Products with various mole ratios were also examined by XRD. The positions of the four characteristic peaks of the PdNi alloyed nanostructures $\left(40.7^{\circ}, 47.3^{\circ}, 69.3^{\circ}\right.$, and $\left.82.8^{\circ}(2 \theta)\right)$ are almost unchanged, regardless of variation in the $\mathrm{Pd}$ precursor concentration, revealing that the fractions of $\mathrm{Ni}$ atoms alloyed with $\mathrm{Pd}$ atoms were the same $(\sim 22 \%$, Table 1$)$. A single Ni peak (marked with the star symbol) which could be assigned to the (111) planes of the face-centeredcubic $(f c c)$ nickel (JCPDS No. 04-0850) is detected when the precursor ratio of $\mathrm{Pd}$ to $\mathrm{Ni}$ is decreased to $0.5: 1$, revealing that some $\mathrm{Ni}$ still remains unconsumed in the final products.

X-ray photoelectron spectroscopy (XPS) was employed to investigate the electronic environment of $\mathrm{Pd}$ in the hollow $\mathrm{Pd}_{1} \mathrm{Ni}_{1}$ nanoparticles (Figure 4(B)). The two peaks around the binding energies of 341 and $336.5 \mathrm{eV}$ are assigned to the $\mathrm{Pd} 3 \mathrm{~d}_{3 / 2}$ (high-energy band) and $3 \mathrm{~d}_{5 / 2}$ (low-energy band), reveal that $\mathrm{Pd}$ is metallic $\mathrm{Pd}(0)$ in the alloyed nanostructures. ${ }^{41}$ When compared to data for pure $\mathrm{Pd} / \mathrm{C}$, the binding energy is lowered by ca. $0.8 \mathrm{eV}$, clearly showing the changes in the electronic structure of Pd, possibly due to the charge transfer between Ni and Pd in the alloyed shell. ${ }^{16}$

To determine the metal composition of the hollow nanoparticles, ICP-MS tests were conducted. Table 1 summarizes the metal compositions of the hollow nanoparticles derived from ICP-MS and XRD. The final Pd/Ni ratios in the products are mostly around 3.0-3.7:1, decreasing as the molar ratio of $\mathrm{Pd}$ to $\mathrm{Ni}$ decreases in the precursor. When the $\mathrm{Pd} / \mathrm{Ni}$ precursor ratio was $0.5: 1$, the results derived from $\mathrm{XRD}$ show that the $\mathrm{Pd} / \mathrm{Ni}$ molar ratio is 2.89 in the alloyed $\mathrm{PdNi}$ 
nanoparticles, excluding the presence of $\mathrm{Ni}$ nanocrystals. When considering the existence of unconsumed Ni, the ICP-MS shows a more accurate ratio of $\mathrm{Pd}: \mathrm{Ni}$, which is about 0.53 .

CV traces were obtained and used for a preliminary study of the electrochemical properties of the synthesized $\mathrm{Pd}_{1} \mathrm{Ni}_{1} / \mathrm{C}, \mathrm{Pd} / \mathrm{C}$, and E-Tek Pt/C (Figure 5(A)). The $\mathrm{CVs}$ are consistent with typical characterized $\mathrm{CV}$ regimes of $\mathrm{Pd}$ or $\mathrm{Pt}$ : typical hydrogen underpotential adsorption/desorption peaks in the potential range of -0.9 to $-0.6 \mathrm{~V}$; a double-layer capacitance region from -0.6 to $-0.4 \mathrm{~V}$; and metal oxidation/reduction peaks in the range between -0.3 and 0.1 V. The electrochemical surface active area (ECSA) was calculated based on the charge transfer in the metal reduction region at around -0.25 (vs. $\mathrm{Ag} / \mathrm{AgCl}$ ), subtracting the double layer correction and assuming $0.405 \mathrm{mC} \mathrm{cm}^{-2}$ for the reduction of a monolayer of $\mathrm{PdO}$ on the catalyst surface and $0.210 \mathrm{mC} \mathrm{cm}^{-2}$ for the reduction of a monolayer of PtO. ${ }^{7}$ The ECSAs are 48.1 and $44.5 \mathrm{~m}^{2} \mathrm{~g}^{-1} \mathrm{Pd}$ for $\mathrm{Pd}_{1} \mathrm{Ni}_{1} / \mathrm{C}$ and $\mathrm{Pd} / \mathrm{C}$, and $59.7 \mathrm{~m}^{2} \mathrm{~g}^{-1} \mathrm{Pd}$ for $\mathrm{Pt} / \mathrm{C}$. Although the particle size of $\mathrm{Pd}_{1} \mathrm{Ni}_{1} / \mathrm{C}$ is much larger than that for $\mathrm{Pd} / \mathrm{C}$, it still shows a slightly higher ECSA than that of the $\mathrm{Pd} / \mathrm{C}$, mainly because of its hollow and porous characteristics.

The thin film rotating-disk electrode (TF-RDE) technique was used to study the ORR activities and kinetics at the $\mathrm{Pd}_{1} \mathrm{Ni}_{1} / \mathrm{C}, \mathrm{Pd} / \mathrm{C}$, and commercial $\mathrm{Pt} / \mathrm{C}$ electrodes. Figure 5(B) shows the ORR polarization curves of these catalysts obtained at a rotation speed of $1600 \mathrm{rpm}$. All the polarization curves display a well-defined diffusion-limiting current region from $-0.8 \mathrm{~V}--0.2 \mathrm{~V}$ and a mixed kinetic-diffusion control region from $0.05 \mathrm{~V}--0.2 \mathrm{~V}$. The half-wave potential of the $\mathrm{Pd}_{1} \mathrm{Ni}_{1} / \mathrm{C}$ for the ORR is $-0.114 \mathrm{~V}(\mathrm{RSD}=1 \%)$, which is slightly higher than that of $\mathrm{Pt} / \mathrm{C}(-0.117$ $\mathrm{V}, \mathrm{RSD}=1 \%)$ and much more positive than that of $\mathrm{Pd} / \mathrm{C}(-0.135 \mathrm{~V}, \mathrm{RSD}=1 \%)$, indicating the hollow shaped $\mathrm{Pd}_{1} \mathrm{Ni}_{1}$ nanoparticles feature a significant enhancement in the electrocatalytic ORR in an alkaline medium compared with $\mathrm{Pd} / \mathrm{C}$ or commercial $\mathrm{Pt} / \mathrm{C}$. 
In order to obtain the kinetics of the ORR, ORR polarization curves were collected at various rotation speeds (Fig. 5(C)), and corresponding Koutecky-Levich (K-L) plots (Figure 5(D)) were drafted from the ORR polarization curves at different potentials. The number of electrons involved per $\mathrm{O}_{2}$-molecule reduction can be determined using the Koutecky-Levich (K-L) equation

$$
\begin{gathered}
j=1 / j_{k}+1 / B \omega^{0.5} \\
{\left[B=0.2 n \mathrm{~F}\left(D_{O 2}\right)^{2 / 3}(v)^{-1 / 6} C_{O 2}\right]}
\end{gathered}
$$

where, $j_{k}$ is the kinetic current, $\omega$ is the electrode rotation rate, $n$ is the transferred electron number, $\mathrm{F}$ is the Faraday constant $\left(\mathrm{F}=96485 \mathrm{C} \mathrm{mol}^{-1}\right), D_{O 2}$ is the diffusion coefficient of $\mathrm{O}_{2}=$ $1.9 \times 10^{-5} \mathrm{~cm}^{2} \mathrm{~s}^{-1}, v$ is the kinetic viscosity $\left(0.01 \mathrm{~cm}^{2} \mathrm{~s}^{-1}\right)$, and $C_{O 2}$ is the bulk concentration of $\mathrm{O}_{2}$ $\left(1.2 \times 10^{-6} \mathrm{~mol} \mathrm{~cm} \mathrm{~cm}^{-3}\right)$. The constant 0.2 is adopted when the rotation speed is expressed in rpm. The transferred electron number was calculated to be $4.20-4.40$ at around $-0.15--0.4 \mathrm{~V}$, revealing that the ORR from $0.15--0.4 \mathrm{~V}$ is dominated by a four-electron (4e) pathway and that $\mathrm{O}_{2}$ is reduced to $\mathrm{OH}^{-}$during the reaction.

To study the electroactivities of the $\mathrm{PdNi} / \mathrm{C}, \mathrm{Pd} / \mathrm{C}$, and $\mathrm{Pt} / \mathrm{C}$ in detail, the kinetic current has been calculated from the ORR polarization curves by considering the mass-transport correction using the Levich-Koutecky equation $\left(1 / i=1 / i_{k}+1 / i_{d}\right.$, where $i_{k}$ is the kinetic current and $i_{d}$ is the diffusion limited current), which is normalized against and then normalized to the mass and specific area of Pd or Pt to compare the mass activities and specific area activities of the catalysts. The mass activity and the specific area activity of the $\mathrm{Pd}_{1} \mathrm{Ni}_{1} / \mathrm{C}$ is $588.97 \mathrm{~mA} \mathrm{~g}^{-1} \mathrm{Pd}$ and $1434 \mu \mathrm{A} \mathrm{cm}{ }^{-2}$, which is 3.89 and 3.92 times higher than those of $\mathrm{Pt} / \mathrm{C}$ or $\mathrm{Pd} / \mathrm{C}$, respectively, indicating the significant improvement of ORR catalytic activity for the hollow $\mathrm{Pd}_{1} \mathrm{Ni}_{1}$. The ORR activities of the other products were also examined. The mass activities were 304.85, 272.43, and $184.41 \mathrm{~mA} \mathrm{~g}^{-1} \mathrm{Pd}$ and the specific area activities were 721.6, 849.1 and $1097 \mu \mathrm{A} \mathrm{cm}{ }^{-2}$ 
for $\mathrm{Pd}_{0.5} \mathrm{Ni}_{1} / \mathrm{C}, \mathrm{Pd}_{2} \mathrm{Ni}_{1} / \mathrm{C}$, and $\mathrm{Pd}_{3} \mathrm{Ni}_{1} / \mathrm{C}$ respectively at $-0.114 \mathrm{~V}$ (vs. $\mathrm{Ag} / \mathrm{AgCl}$ ). Comparing with $\mathrm{Pt} / \mathrm{C}\left(151.3 \mathrm{~mA} \mathrm{~g}^{-1} \mathrm{Pd}\right)$ or $\mathrm{Pd} / \mathrm{C}\left(162.96 \mathrm{~mA} \mathrm{~g}^{-1}{ }_{\mathrm{Pd}}\right)$, we infer that the enhanced ORR activity of the $\mathrm{PdNi} / \mathrm{C}$ can be ascribed to the unique hollow alloyed structures with porous shells of nanoparticles. Moreover, the changes in the surface electronic features through the introduction of a second metal to Pd would also contribute to the increased activity. ${ }^{7}$ As suggested in the XRD patterns (Figure 4(A)), the alloyed PdNi nanoparticles with a slightly smaller lattice parameters will cause the compress surface strain effect on the Pd skin (suggested in Figure 4(B)) which is beneficial for the oxygen reduction reaction. ${ }^{7,42}$

A chronoamperometric study was conducted to determine the durability of the catalyst for the ORR (Fig 5(F)). During the long ( $8000 \mathrm{~s})$ ORR test at $-0.2 \mathrm{~V}$, a 5\% current loss for the hollow shaped $\mathrm{Pd}_{1} \mathrm{Ni}_{1} / \mathrm{C}$ was observed. In contrast, for $\mathrm{Pd} / \mathrm{C}$ or commercial $\mathrm{Pt} / \mathrm{C}$, the current losses under identical conditions are more than $10 \%$. These results clearly indicate the hollow PdNi/C is much more stable than the commercial $\mathrm{Pt} / \mathrm{C}$ or $\mathrm{Pd} / \mathrm{C}$ in terms of the catalytic activities of oxygen.

The TF-RDE technique is useful for identifying candidate materials but tests operated under conditions that are much closer to fuel cell operating conditions are necessary to demonstrate the practical performances of the electrocatalysts,. Anion exchange membrane fuel cell tests as described previously ${ }^{10}$ were carried out in order to evaluate the performance of the catalysts in a practical environment. Figure 6 shows the polarization curves and power density curves of AEMFC tests with commercial E-Tek $\mathrm{Pt} / \mathrm{C}$ and $\mathrm{Pd}_{1} \mathrm{Ni}_{1} / \mathrm{C}$ cathode catalysts, respectively. The peak power density obtained with the commercial E-Tek Pt/C electrocatalysts is $92 \mathrm{~mW} \mathrm{~cm}^{-2}$ at the loading of $0.4 \mathrm{mg} \mathrm{cm}^{-2}$, which is compatible to the previous results. ${ }^{10}$ Under the same testing conditions, the hollow $\mathrm{Pd}_{1} \mathrm{Ni}_{1} / \mathrm{C}$ electrode exhibits much higher power density and current 
density than those with $\mathrm{Pt} / \mathrm{C}$. The peak power density of the hollow $\mathrm{Pd}_{1} \mathrm{Ni}_{1} / \mathrm{C}$ electrode obtained at $0.4 \mathrm{~V}$ is $150 \mathrm{~mW} \mathrm{~cm}^{-2}$, which is more than 1.7 times higher than that with the commercial $\mathrm{Pt} / \mathrm{C}$ $\left(90 \mathrm{~mW} / \mathrm{cm}^{2}\right)$. In addition, at $0.4 \mathrm{~V}$ the current density of the hollow $\mathrm{Pd}_{1} \mathrm{Ni}_{1} / \mathrm{C}$ is $375 \mathrm{~mA} \mathrm{~cm}^{-2}$, which is 1.5 times larger than that of the $\mathrm{Pt} / \mathrm{C}$ at the same voltage (current then $240 \mathrm{~mA} \mathrm{~cm}^{-2}$ ). These results, which are consistent with the RDE results (Figure 5), provide clear evidence to suggest that the $\mathrm{Pd}_{1} \mathrm{Ni}_{1} / \mathrm{C}$ electrocatalysts have the potential to perform as more promising and efficient electrocatalysts in alkaline membrane fuel cells (a working, real environment) when compared with state-of-the-art commercial Pt/C electrocatalyst.

\section{Conclusion}

We have described a modified galvanic replacement method to synthesize hollow PdNi nanoparticles with superior ORR electrocatalytic performance in an alkaline environment. XRD, TEM, and HR-TEM images show that the synthesized hollow nanoparticles are alloyed nanostructures with an average size of $30 \mathrm{~nm}$ and a shell thickness of $5 \mathrm{~nm}$. Electrochemical tests have revealed that the PdNi hollow nanoparticles are superior ORR catalysts when compared to commercial $\mathrm{Pt} / \mathrm{C}$ or $\mathrm{Pd} / \mathrm{C}$. The improved performance is assigned to the unique hollow porous structure and changes in the electronic structures when a second metal (Ni) is introduced in addition to the $\mathrm{Pd}$. Moreover, practical fuel cell tests have revealed that PdNi catalysts, with much lower cost, could work as more efficient catalysts than commercial $\mathrm{Pt} / \mathrm{C}$ under real operating conditions. This method could be used to synthesize other Pd-based hollow nanostructured electrocatalysts with low cost and high catalytic performance for future AEMFCs. 


\section{AUTHOR INFORMATION}

\section{Corresponding Author}

*E-mail: junc@uow.edu.au

\section{Notes}

The authors declare no competing financial interests.

\section{ACKNOWLEDGMENT}

The authors acknowledge the continuous financial support by Australian Research Council Centre of Excellence for Electromaterials Science (ACES) and ARC DP110103909, the Australian National Fabrication Facility (ANFF) for provision of services and equipment access, and the use of facilities within the UOW Electron Microscopy Centre. Work on energy materials and functional devices at the University of Surrey is funded by the UK's Engineering and Physical Sciences Research Council (EPSRC).

\section{REFERENCES}

1. Wu, G.; MacK, N. H.; Gao, W.; Ma, S.; Zhong, R.; Han, J.; Baldwin, J. K.; Zelenay, P., ACS Nano 2012, 6, 9764-9776.

2. Debe, M. K., Nature 2012, 486, 43-51.

3. Lim, B.; Jiang, M.; Camargo, P. H. C.; Cho, E. C.; Tao, J.; Lu, X.; Zhu, Y.; Xia, Y., Science 2009, 324, 1302-1305.

4. Wang, S.; Iyyamperumal, E.; Roy, A.; Xue, Y.; Yu, D.; Dai, L., Angew. Chem., Int. Ed. 2011, 50, 11756-11760. 
5. Hong, J. W.; Kang, S. W.; Choi, B. S.; Kim, D.; Lee, S. B.; Han, S. W., ACS Nano 2012, 6, 2410-2419.

6. Sekol, R. C.; Li, X.; Cohen, P.; Doubek, G.; Carmo, M.; Taylor, A. D., Appl. Catal., B 2013, 138-139, 285-293.

7. Zhang, Z.; More, K. L.; Sun, K.; Wu, Z.; Li, W., Chem. Mater. 2011, 23, 1570-1577.

8. Gu, S.; Cai, R.; Luo, T.; Chen, Z.; Sun, M.; Liu, Y.; He, G.; Yan, Y., Angew. Chem., Int. Ed. 2009, 48, 6499-6502.

9. Varcoe, J. R.; Slade, R. C. T.; Lam How Yee, E., Chem. Commun. 2006, 0, 1428-1429.

10. Varcoe, J. R.; Slade, R. C. T., Electrochem. Commun. 2006, 8, 839-843.

11. Shim, J. H.; Kim, J.; Lee, C.; Lee, Y., Chem. Mater. 2011, 23, 4694-4700.

12. Sun, W.; Hsu, A.; Chen, R., J. Power Sources 2011, 196, 4491-4498.

13. Koenigsmann, C.; Santulli, A. C.; Sutter, E.; Wong, S. S., ACS Nano 2011, 5, 7471-7487.

14. Halder, A.; Patra, S.; Viswanath, B.; Munichandraiah, N.; Ravishankar, N., Nanoscale 2011, 3, 725-730.

15. Lee, K.; Kang, S. W.; Lee, S. U.; Park, K. H.; Lee, Y. W.; Han, S. W., ACS Appl. Mater. Interfaces 2012, 4, 4208-4214.

16. Chen, L.; Guo, H.; Fujita, T.; Hirata, A.; Zhang, W.; Inoue, A.; Chen, M., Adv. Funct. Mater. 2011, 21, 4364-4370.

17. Zhang, L.; Hou, F.; Tan, Y., Chem. Commun. 2012, 48, 7152-7154. 
18. Caixia, X.; Yan, Z.; Liqiang, X.; Xiufang, B.; Houyi, M.; Yi, D., Chem. Mater. 2009, 21, 3110-3116.

19. Fouda-Onana, F.; Bah, S.; Savadogo, O., J. Electroanal. Chem. 2009, 636, 1-9.

20. Shih, Z.-Y.; Wang, C.-W.; Xu, G.; Chang, H.-T., J. Mater. Chem. A 2013, 1, 4773-4778.

21. Neergat, M.; Gunasekar, V.; Rahul, R., J. Electroanal. Chem. 2011, 658, 25-32.

22. Shao, M.-H.; Sasaki, K.; Adzic, R. R., J. Am. Chem. Soc. 2006, 128, 3526-3527.

23. Fernández, J. L.; Raghuveer, V.; Manthiram, A.; Bard, A. J., J. Am. Chem. Soc. 2005, $127,13100-13101$.

24. Slanac, D. A.; Hardin, W. G.; Johnston, K. P.; Stevenson, K. J., J. Am. Chem. Soc. 2012, $134,9812-9819$.

25. Kim, J.-H.; Bryan, W. W.; Chung, H.-W.; Park, C. Y.; Jacobson, A. J.; Lee, T. R., ACS Appl. Mater. Interfaces 2009, 1, 1063-1069.

26. Koenigsmann, C.; Sutter, E.; Adzic, R. R.; Wong, S. S., J. Phys. Chem. C 2012, 116, 15297-15306.

27. Liu, M.; Lu, Y.; Chen, W., Adv. Funct. Mater. 2013, 23, 1289-1296.

28. Xu, C.; Wang, L.; Wang, R.; Wang, K.; Zhang, Y.; Tian, F.; Ding, Y., Adv. Mater. 2009, $21,2165-2169$.

29. Sun, Y.; Xia, Y., J. Am. Chem. Soc. 2004, 126, 3892-3901. 
30. Mayers, B.; Jiang, X.; Sunderland, D.; Cattle, B.; Xia, Y., J. Am. Chem. Soc. 2003, 125, 13364-13365.

31. Zhang, H.; Jin, M.; Liu, H.; Wang, J.; Kim, M. J.; Yang, D.; Xie, Z.; Liu, J.; Xia, Y., ACS Nano 2011, 5, 8212-8222.

32. Zhang, W.; Yang, J.; Lu, X., ACS Nano 2012, 6, 7397-7405.

33. Chen, G.; Xia, D.; Nie, Z.; Wang, Z.; Wang, L.; Zhang, L.; Zhang, J., Chem. Mater. 2007, 19, 1840-1844.

34. Vasquez, Y.; Sra, A. K.; Schaak, R. E., J. Am. Chem. Soc. 2005, 127, 12504-12505.

35. Li, H.; Lin, H.; Hu, Y.; Li, H.; Li, P.; Zhou, X., J. Mater. Chem. 2011, 21, 18447-18453.

36. Yang, J.; Chen, X.; Yang, X.; Ying, J. Y., Energy Environ. Sci. 2012, 5, 8976-8981.

37. Li, H.; Zhu, Z.; Liu, J.; Xie, S.; Li, H., J. Mater. Chem. 2010, 20, 4366-4370.

38. Yang, L.; Hu, C.-G.; Wang, J.-L.; Yang, Z.-X.; Guo, Y.-M.; Bai, Z.-Y.; Wang, K., Chem. Commun. 2011, 47, 8581-8583.

39. Paulus, U. A.; Schmidt, T. J.; Gasteiger, H. A.; Behm, R. J., J. Electroanal. Chem. 2001, 495, 134-145.

40. Wang, M.; Zhang, W.; Wang, J.; Minett, A.; Lo, V.; Liu, H.; Chen, J., J. Mater. Chem. A 2013, 1, 2391-2394.

41. Zhu, L. D.; Zhao, T. S.; Xu, J. B.; Liang, Z. X., J. Power Sources 2009, 187, 80-84. 
42. Liu, Y.; Hangarter, C. M.; Bertocci, U.; Moffat, T. P., J. Phys. Chem. C 2012, 116, 78487862. 
Figure 1

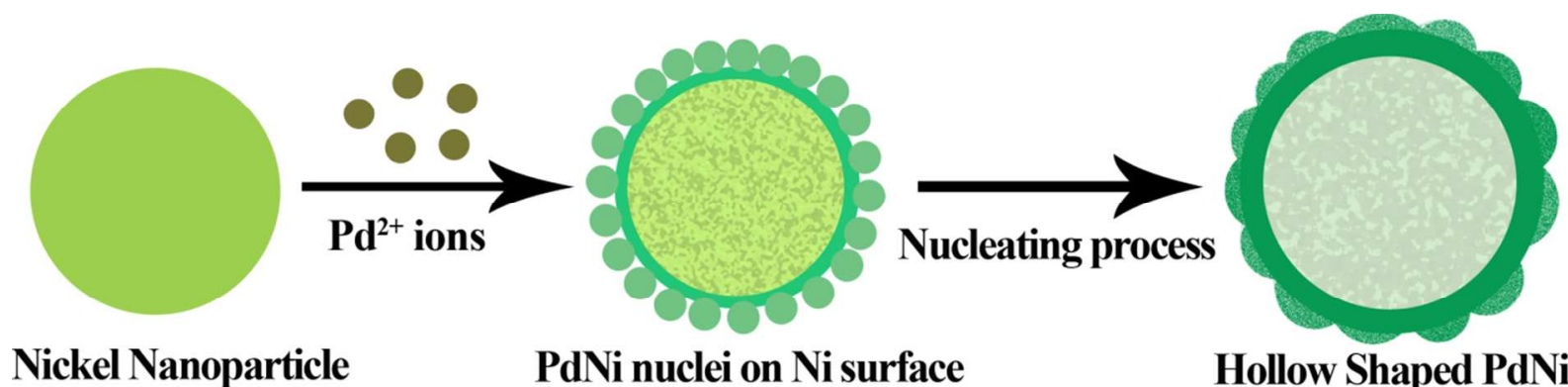

Nickel Nanoparticle PdNi nuclei on Ni surface

Hollow Shaped PdNi

Figure 1. Schematic illustration of the formation of hollow PdNi nanoparticles. 
Figure 2
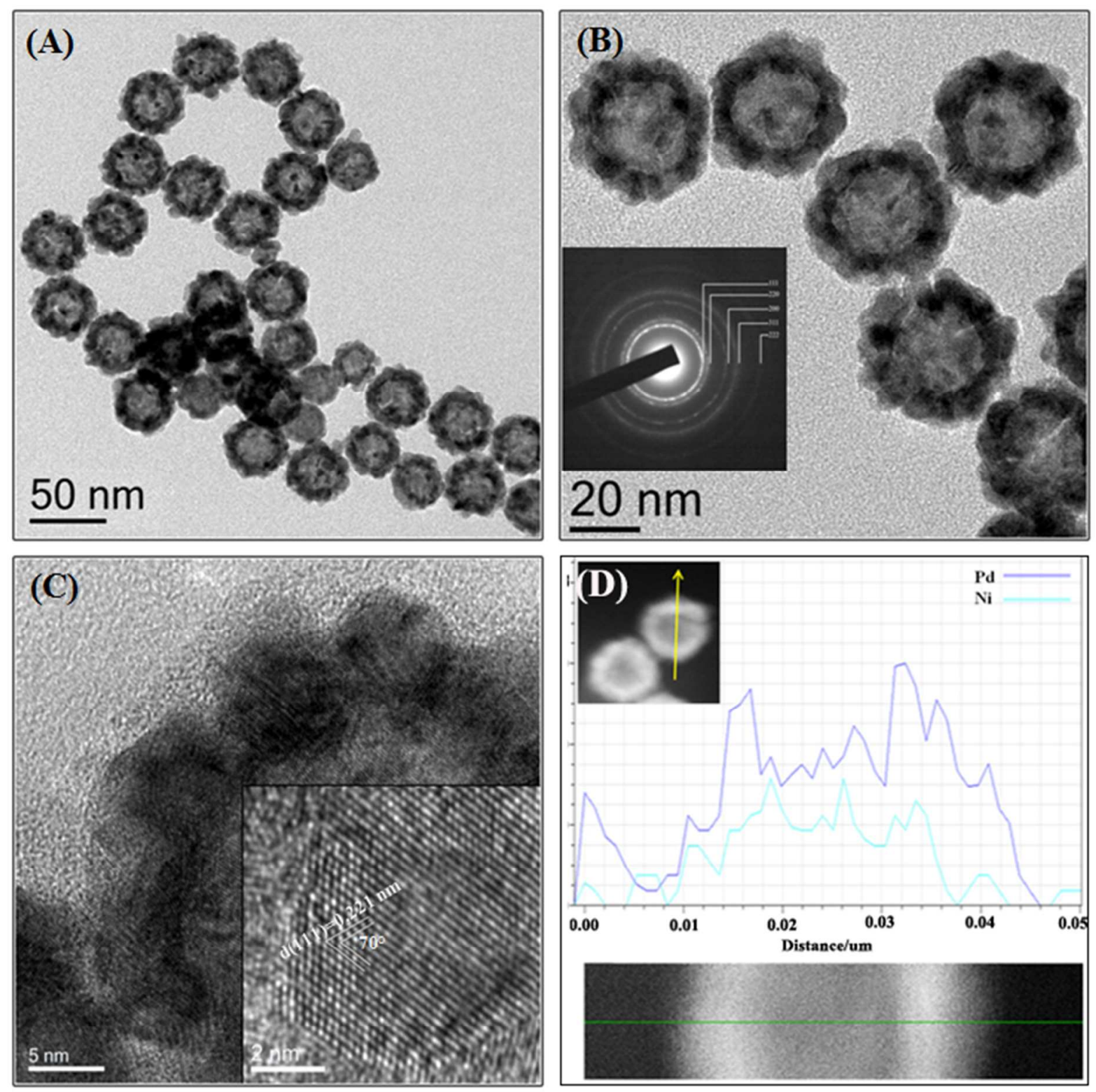

Figure 2. (A) low magnification TEM image and (B) high magnification TEM image of the $\mathrm{Pd}_{1} \mathrm{Ni}_{1}$ hollow nanoparticles (inset: corresponding SAED pattern); (C) representative high resolution (HR) TEM image of the hollow PdNi nanoparticles, with the inset showing higher resolution with lattice spacing; (D) line-scanning profile across a $\mathrm{Pd}_{1} \mathrm{Ni}_{1}$ hollow nanoparticle (insets: HADF-STEM images of the scanned nanoparticle). 
Figure 3

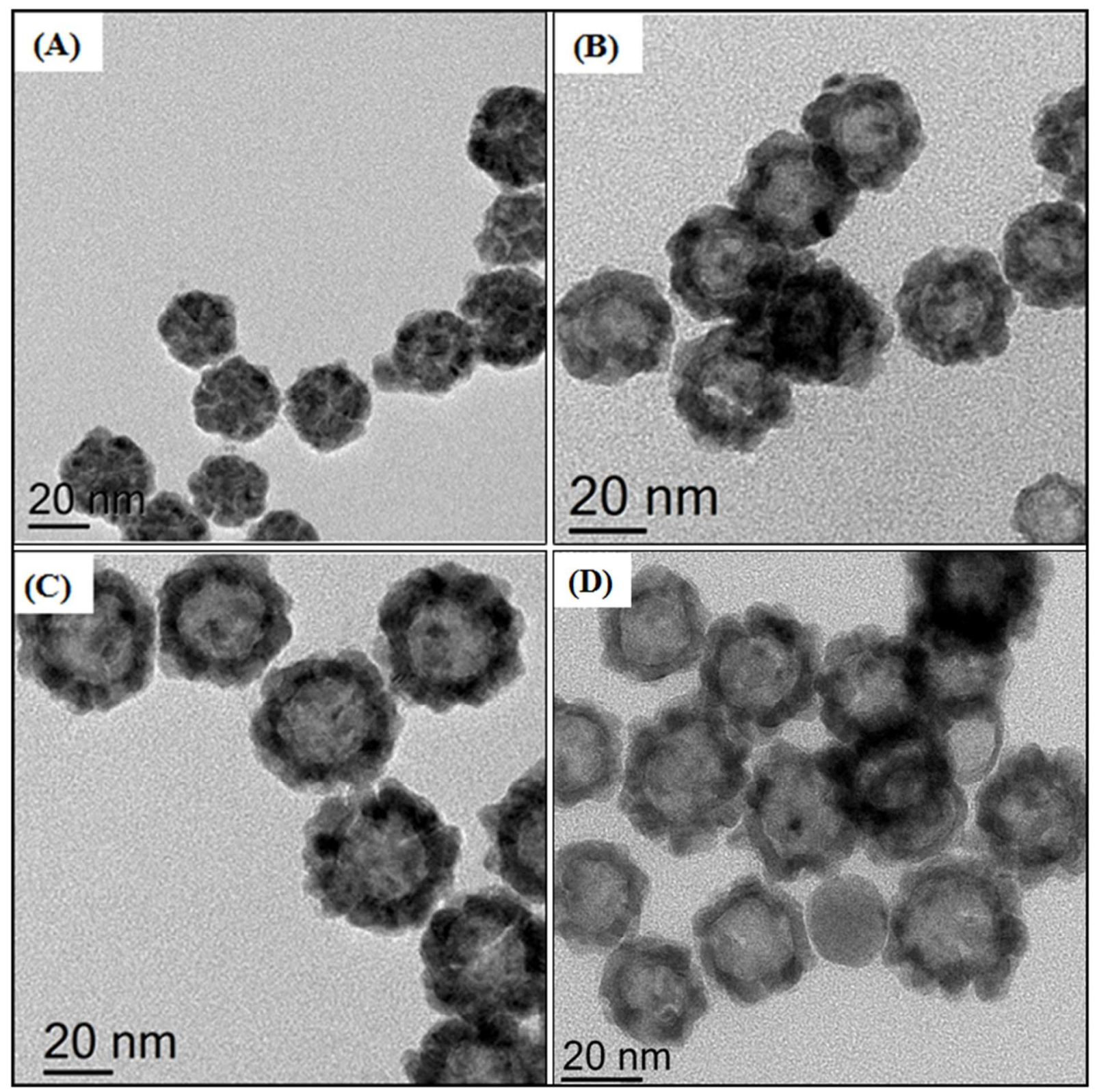

Figure 3. Typical TEM images of PdNi hollow nanoparticles with different $\mathrm{Pd} / \mathrm{Ni}$ precursors ratios; the molar ratios of $\mathrm{Pd} / \mathrm{Ni}$ are (A) $3: 1$, (B) $2: 1$, (C) $1: 1$, (D) $0.5: 1$. 
Figure4
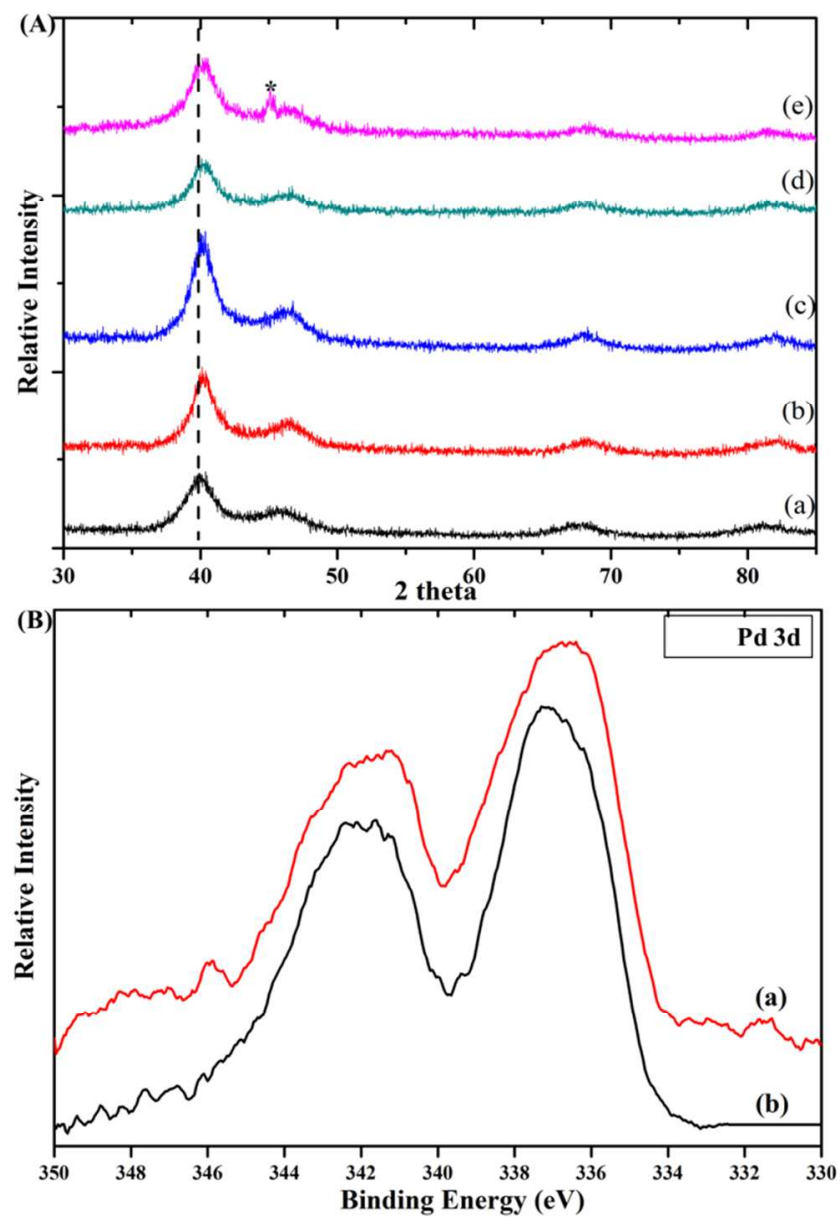

Figure 4. (A) XRD patterns of the synthesized nanoparticles: (a) "homemade" Pd/C, (b-e) PtNi hollow nanoparticles with various $\mathrm{Pt} / \mathrm{Ni}$ products: (b) to (e) $\mathrm{Pd}_{0.5} \mathrm{Ni}_{1} / \mathrm{C} \mathrm{Pd}_{1} \mathrm{Ni}_{1} / \mathrm{C}, \mathrm{Pd}_{2} \mathrm{Ni}_{1} / \mathrm{C}$, and $\mathrm{Pd}_{3} \mathrm{Ni}_{1} / \mathrm{C}$; (B) XPS spectra of $\mathrm{Pd} 3 \mathrm{~d}$ in (a) $\mathrm{Pd}_{1} \mathrm{Ni}_{1} / \mathrm{C}$ and (b) "homemade" $\mathrm{Pd} / \mathrm{C}$. 
Table 1. Summary of metal contents derived from ICP-MS and XRD.

\begin{tabular}{ccccc}
\hline Precursors & Derived from ICP-MS & \multicolumn{3}{c}{ Derived from XRD* } \\
\hline & Pd/Ni mole ratio & $\begin{array}{c}\text { Lattice Constant } \\
(\AA)\end{array}$ & $\begin{array}{c}\text { Pd mole } \\
\text { fraction }\end{array}$ & $\begin{array}{c}\text { Pd/Ni mole } \\
\text { ratio }\end{array}$ \\
3 & 3.44 & 3.812 & 78.92 & 3.74 \\
2 & 3.32 & 3.802 & 76.22 & 3.20 \\
1 & 3.06 & 3.798 & 75.13 & 3.04 \\
0.5 & 0.53 & 3.795 & 74.32 & 2.89
\end{tabular}

* The lattice parameters were the average lattice spacings calculated from the three major reflections ((111), (200), and (220)) of the alloyed nanoparticles; the Pd molar fraction were obtained assuming Vegard's law. 
Figure 5
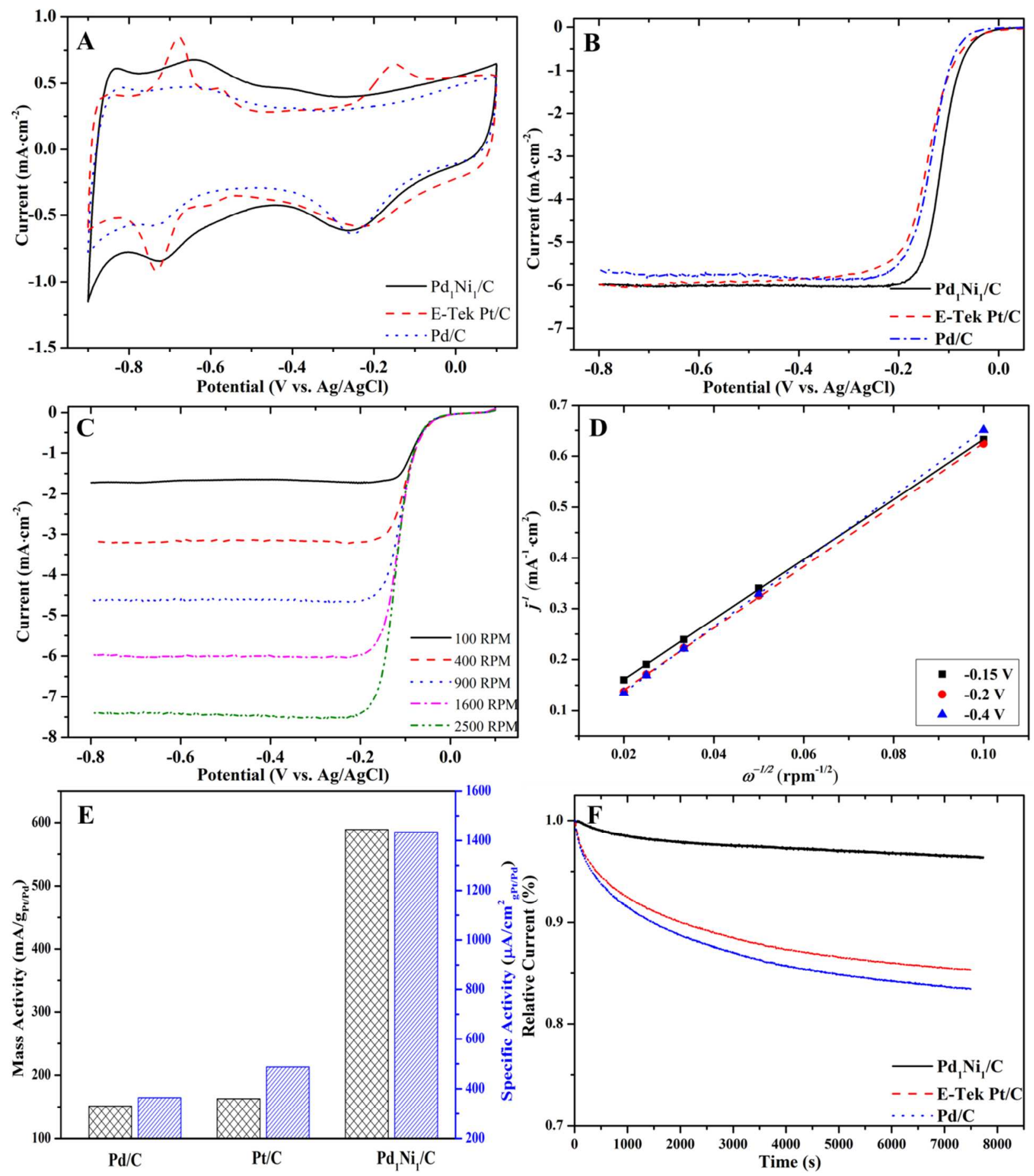

Figure 5. (A) CVtraces and (B) ORR polarization curves of the $\mathrm{Pd}_{1} \mathrm{Ni}_{1} / \mathrm{C}$, home-made $\mathrm{Pd} / \mathrm{C}$, and commercial E-Tek Pt/C. (C) ORR polarization curves of the $\mathrm{Pd}_{1} \mathrm{Ni}_{1} / \mathrm{C}$ at various rotation rates. 
(D) K-L plots derived from the ORR curves of the $\mathrm{Pd}_{1} \mathrm{Ni}_{1} / \mathrm{C}$ at different potentials. (E) Mass activities and specific activities of the Pd1Ni1/C, Pd/C, and E-Tek Pt/C at $-0.1 \mathrm{~V}$ and $-0.2 \mathrm{~V}$. (F) Chronoamperometric responses of the electrocatalysts at $-0.2 \mathrm{~V}$ with rotation rate of $1600 \mathrm{rpm}$. ORR curves and chronoamperometric responses were measured in $\mathrm{O}_{2}$-saturated $\mathrm{KOH}(\mathrm{aq})(0.1$ mol $\mathrm{L}^{-1}$ ) solution with a scan rate of $10 \mathrm{mV} \mathrm{s}^{-1}$. 
Figure 6

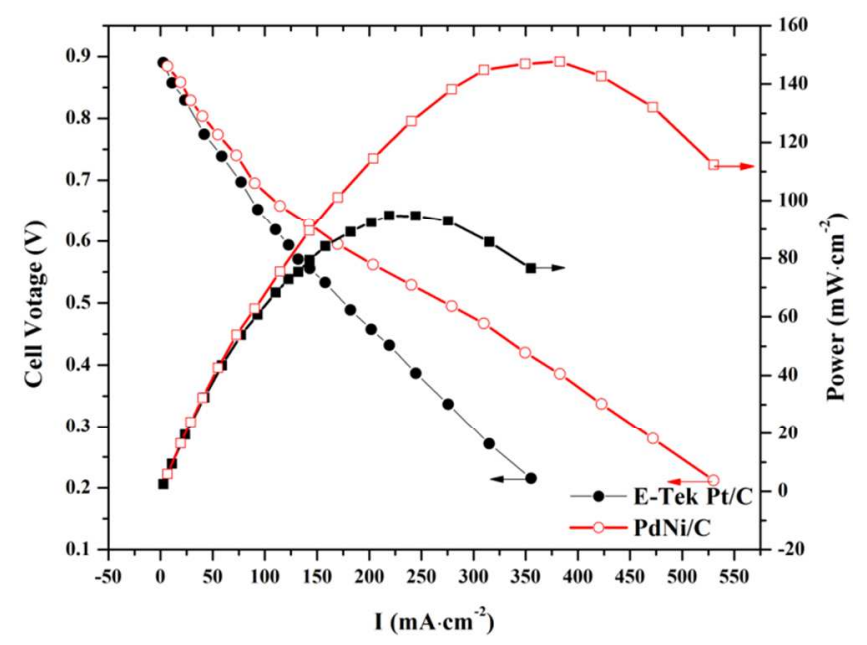

Figure 6. AEMFC polarization curves (round symbols) and power density curves (square symbols) of a single cell test using E-Tek Pt/C (filled symbols) and PdNi/C (hollow symbols) as cathode catalysts with a loading amount of $0.4 \mathrm{mg} \mathrm{cm}^{-2}$. Operating conditions: cell temperature $60^{\circ} \mathrm{C}$, humidifier temperatures $60^{\circ} \mathrm{C}$ for both $\mathrm{H}_{2}$ and $\mathrm{O}_{2}$, flow rate $0.08 \mathrm{~L} \mathrm{~min}{ }^{-1}$, and back pressure 15 psi for both $\mathrm{H}_{2}$ and $\mathrm{O}_{2}$. 
For Table of Contents Only

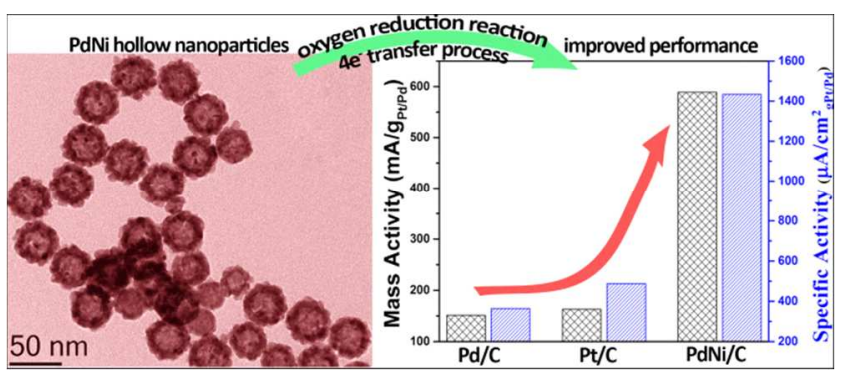

